\title{
НАВЧАННЯ Й УПРАВЛІННЯ ОСВІТНІМ ПРОЦЕСОМ
}

\section{Швай P. I.}

\section{ВСТУП}

Освітній процес - єдність навчання й учіння, цілеспрямований процес двосторонньої діяльності викладача й учня, а навчання і виховання можна трактувати як певний вид керування розвитком психічних процесів і властивостей особистості у взаємозв'язку 3 питаннями змісту, методів і форм навчання. Якщо розглядати освітній процес із погляду теорії управління, то для успішного керування цим процесом, ефективного впливу на елементи педагогічної системи, зокрема учнів, необхідний аналіз діяльності інших елементів (організаторів освітнього процесу). Система «учитель - учень» підпорядковується теорії управління. У цій системі 3 погляду традиційної парадигми учителя визначають як керуючого, а учня - як керованого. Особливістю системи «викладач - учень» $є$ те, що учень $\epsilon$ мислячою активною особистістю, яка свідомо реагує на команди викладача, активно бере участь в освітньому процесі. Він може бути союзником учителя або противником (свідомими чи несвідомим). Метою управління $є$ досягнення такого стану системи, що $є$ бажаний і можливий і відповідає освітнім цілям. Під ефективним управлінням розуміємо економне у часі та засобах досягнення мети системи. Тому одним із критеріїв ефективності навчання є час вивчення, осмислення, розуміння та засвоєння матеріалу, а пошук резерву часу $є$ одним із напрямів інтенсифікації освітнього процесу.

\section{1. Підходи до організації управління освітнім процесом}

Педагог повинен підпорядковувати всі види діяльності головній меті педагогічної системи. Він моделює свою майбутню взаємодію з учнем, робить відбір засобів, за допомогою яких можна досягнути поставлену освітню мету. Набуті компетентності учня $є$ результатом його інтеракції з педагогом. У реальному педагогічному процесі мета визначальний чинник, що детермінує зміст навчання, його методи та форми. Мета є тим стрижнем, навколо якого педагог об'єднує всі педагогічні засоби в систему. Розуміння викладачем мети освітнього процесу стимулює пошук ефективних засобів іiі реалізації. Виділимо три критерії класифікації цілей: за змістом, за рівнем управління і за часом вирішення завдань. Способи досягнення цілей можна поділити на три групи. Перша група - способи, пов'язані з частковими затратами 
часу на виконання поставленого завдання. Учитель квоту часу визначає емпіричним шляхом, і правильність такого рішення цілком залежить від методичної підготовки вчителя, від організації освітнього процесу. Простежується прагнення до мінімізації затрат часу. Друга група методів окреслює мінімальні затрати способів і прийомів вирішення завдань, які постають перед вчителем і учнем. Третя група пов'язана 3 мінімальним відхиленням від цільових показників.

Для організації процесу управління необхідно сформулювати мету. Педагогічний процес $\epsilon$ неперервним, тому потрібна безперервна корекція мети. Необхідно враховувати динаміку ії зміни, корелювати іiі з динамікою розвитку особистості учня. Від цього залежить і швидкість розв'язання педагогічних завдань. Відомо, що навчання і розвиток особистості - це взаємозумовлені процеси. У процесі навчання важливим $є$ не лише передача певної системи знань, а й забезпечення всебічного розвитку особистості, враховуючи природні задатки особистості, закономірності й особливості, рівень розвитку логікомислительних операцій і дій, що їх виконує учень у процесі навчання. Так виникає необхідність коригування учителем своєї діяльності як організатора і керівника освітнього процесу. Контроль за діяльністю будь-якої системи є стимулом до роботи. Система «учень - учитель» $\epsilon$ особливою в тому сенсі, що маємо справу з суб'єктом, котрий розвивається. Внаслідок поганого зворотного зв'язку вчитель у процесі навчання часто не знає, як та чи інша інформація усвідомлюється учнями. Через відсутність зворотного зв'язку відбуваються суттєві викривлення у засвоєнні навчального матеріалу. Якщо учень лише засвоює готову інформацію, лише заучує певний об'єм інформації, то позитивним у цьому процесі $є$ лише тренування пам'яті, однак цього аж ніяк не вистачає для всебічного розвитку особистості. У процесі навчання учні, розв'язуючи певні проблеми, повинні вдаватися до багатьох мислительних дій. У цьому разі активізуються різноманітні психічні процеси.

У процес пошуку нових знань включаються як алгоритмічні, так і евристичні прийоми. На відміну від прийомів алгоритмічного типу, евристичні спрямовані не на формально-логічний, а на змістовий, семантичний аналіз проблем. Це стимулює включення у процес вирішення проблем наочно-образного мислення, дозволяє використати його переваги над вербальним мисленням, його симультативність, можливість узагальненого сприймання досліджуваної проблеми, що полегшує перебіг характерних для продуктивного мислення інтуїтивних процесів.

Інтенсивна і довготривала розумова діяльність у школярів розвиває втому, настання якої уповільнюється при переключенні на інший вид діяльності. Працездатність організму під час навчальної діяльності закономірно змінюється. Існують дуже складні взаємовідношення між 
розумовими здібностями й інтелектуальною працездатністю. Наявність великих розумових здібностей ще не гарантує високий рівень ініціативи. Досить часто здібні люди задовольняються вирішенням поставленої перед ними проблеми більш елементарним способом. Суттєвий вплив на успішність i специфіку навчальної діяльності мають індивідуальні відмінності в її мотивації.

Швидкий розвиток наук постійно збільшує диспропорцію між зростанням наукового пізнання і можливістю засвоєння великого обсягу знань. Зростає диспропорція між рівнем розвитку можливостей мозку учня, рівнем його психічної готовності сприймати нову інформацію i досягненим рівнем наукового пізнання. Зокрема, різке збільшення об'єму знань із фізики, які на сучасному етапі необхідно засвоювати учням, а також вимога підвищення якості знань спонукають до пошуку можливостей для підвищення рівня управління процесом учіння.

3 погляду управління освітній процес завжди був і $є$ інформаційним процесом управління за своєю суттю, незважаючи на те, методами якої педагогіки (авторитарної суб'єкт-об'єктної, гуманістичної суб'єктсуб'єктної тощо) і якими конкретними засобами в ньому відбувається обмін інформацією в системі «учитель - учні». Різні педагогічні системи передбачають різні моделі управління освітнім процесом. Так, наприклад, авторитарній педагогіці, яка трактує учня як об'єкт педагогічного впливу (об'єкт управління), відповідає така модель навчального процесу, де вчитель: по-перше, є єдиною керуючою ланкою, по-друге, безпосередньо керує (намагається керувати) всіма складовими частинами освітнього процесу за наперед спланованим жорстким сценарієм. Власне, у цій педагогіці роль вчителя як безпосереднього керівника найчіткіше виражена, бо саме вчитель і лише він визначає як шляхи передачі інформації та зворотного зв'язку управління, так і характер (обсяг і зміст) самої інформації. У разі переходу до суб'єктсуб'єктної педагогіки (гуманістичної, співробітництва) роль учителя як керівника суттєво змінюється. Вчитель, по-перше, вже не є єдиною керуючою ланкою, бо поряд із ним з'являється ще один суб'єкт навчального (а отже, керівник) інформаційного процесу - учень; подруге, від безпосереднього управління всіма складовими частинами освітнього процесу вчитель намагається відійти, передавши деякі з цих функцій учневі, тобто змінюється сам характер управління: від безпосереднього управління процесом навчання до керівництва процесом перетворення учня у співкерівника.

В ідеальному вираженні суб'єкт-суб'єктна педагогіка покликана навчити учня не навчального предмета, а навчити його, як самому вивчити цей предмет. Тобто майстерність вчителя тут полягає у його вмілій, дозованій передачі своїх управлінських функцій учневі в міру готовності останнього до цього. 
Двом цим педагогічним підходам у відповідність можна поставити два різні управлінські завдання. Першому - завдання, де треба добитися передачі-прийому заданої наперед кількості та якості інформації 3 найменшими затратами часу, матеріалів, енергії тощо. Другому завдання, де за наперед заданих затрат часу, матеріалів тощо треба добитися передачі-прийому якнайбільшої кількості та якості інформації.

Якщо перше завдання достатньо добре реалізоване, то для другого ще можна залучити різні шляхи його реалізації, одним із яких $є$ ширше застосування діяльнісного підходу. Важливо виробити таку модель освітнього процесу, щоб учні 3 найменшими затратами ефективно засвоювали той обсяг знань, виробили такі уміння та навички, що надалі дозволить їм вміло орієнтуватися і керувати щораз більшим потоком інформації.

За таких умов функції вчителя змінюються від інформаційнопояснювальних до організаційно-управлінських. Важливим є пізнання закономірностей і пошук оптимальних способів управління освітнім процесом. Педагогічні системи - це цілеспрямовані та самоорганізуючі утворення. Активність учнів підсилюється взаємодією «педагог навчальна інформація», яка буде предметом уваги, засвоєння і діяльності учнів. Педагог планує майбутню діяльність учнів на основі опрацювання різних варіантів і вибору найбільш відповідного. Самокерівні системи управління містять керівну [під]систему і [під]систему керовану, які $\epsilon$ основними і також простими іiі складовими частинами. Між ними відбувається обмін інформацією, а саме: керівна [під]система подає інформацію керованій, внаслідок дії зворотного зв'язку керована [під]система інформує про наслідки спільної діяльності, що необхідно для оптимального способу розв'язання завдань. Обмін інформацією відображає взаємозв'язок між елементами, що є однією з ознак системи, яку можна спостерігати у процесі навчання на уроці. Каналом прямого зв'язку вчитель передає навчальну інформацію учням. Для з'ясування рівня засвоєння учнями навчальної інформації вчитель повинен виконати операції для отримання зворотної інформації від учнів про розуміння i засвоєння навчального матеріалу. Виходячи зі стану зворотної інформації, керуючий (учитель) визначає стратегію своєї подальшої діяльності 3 управління всією системою. Найбільша ефективність навчання досягається тоді, коли знайдено оптимальний варіант організації освітнього процесу, а сучасний процес навчання належить до недостатньо керованих процесів.

Отже, управління процесом навчання містить у собі два взаємопов'язані процеси: організацію діяльності учня і контроль цієї діяльності. Об'єктом управління в навчанні виступає учень (як керована і самокерована система), об'єктом контролю - навчально-пізнавальна діяльність цього учня, предметом управління $\epsilon$ отримання учнем запланованого результату навчання, предметом контролю - протікання 
процесу навчально-пізнавальної діяльності, орієнтованого на запланований результат. Фактично йдеться про управління активною системою (учень), здатного до самоконтролю, самоуправління. Проблему управління навчанням не можна віднести до суто дидактичної. За умов переходу від традиційної системи до пошуково-творчих схем навчання особливо гостро постає проблема управління пізнавальною діяльністю учнів. Надалі залишаються не врахованими в дидактиці значні теоретичні та практичні доробки з цієї проблеми у таких галузях знань, як філософія, соціологія, фізіологія, нейрофізіологія тощо. Вирішення проблеми управління процесом навчання необхідно шукати на межі інших суміжних із дидактикою наук, а саме: психології, інформатики, логіки тощо.

У зв'язку 3 перевантаженням навчальних програм потрібне таке управління процесом учіння, коли знання - це система високого рівня узагальнення, в якій за окремими елементами учень на основі суджень міг би відшукати додаткову інформацію, необхідну для оперування новими знаннями. Необхідно орієнтувати учнів на виділення фундаментальних знань, необхідних для засвоєння, які потрібно виокремлювати від іншого другорядного матеріалу.

Методика навчання пов'язана 3 цілями та змістом навчання. Учитель вибирає метод відповідно до цілей навчання й адаптує його до конкретних умов, що позначається на досягнутих результатах навчання. Навчальний метод поєднує в собі цілеспрямовану діяльність учителя (навчальний аспект) і активне ставлення учня до цієї діяльності - його учіння. Однак на результат навчальної діяльності впливають, крім методів, різноманітні інші чинники: зміст, цілі, принципи навчання, учитель, учні тощо.

У виборі методу учителем для успішного й ефективного управління освітньою діяльністю учнів мають враховуватися особливості психічних процесів: мислення, уваги, пам'яті. Психіка учня формується в навчальній діяльності, у взаємодії з об’єктами його пізнання, учіння.

Багато чинників впливає на процес учіння. Враховуючи їхні різноманітні впливи на цей процес, не можна констатувати сталість тих чи інших параметрів для визначення ефективності навчання. Серед таких чинників потрібно виділити необхідність врахування диференційованості навчання, різні індивідуальні особливості перебігу психічних процесів, відмінності учнів у навичках працювати. Одним із важливих моментів у цьому процесі $є$ рівень педагогічної майстерності педагога, його стиль роботи. Ефективність освітнього процесу залежить від спільної злагодженої діяльності вчителя i учнів, що здійснюється за умов колективного навчання. Ефективним вважається навчання, у процесі якого учні набувають нові компетентності, докладаючи мінімум зусиль і протягом мінімального часу. Можна виділити три основні показники ефективності: час, енергію, яку повинні затратити вчитель і учень для 
досягнення успішних результатів, і результати навчальної діяльності. У понятті ефективності навчання потрібно наголосити на його суттєвій стороні, а саме на якості всього освітнього процесу. Отже, одним із першочергових завдань постало удосконалення організаційноуправлінської діяльності вчителя.

\section{2. Модель навчання фізики в системі управління освітнім процесом}

Теоретичні знання, отримані у готовому вигляді, а не виведені самостійно із практичного досвіду, не пов'язаного з усією цілісною системою уявлень людини, мало придатні до вжитку i легко втрачаються. Лише сам процес отримання (а не заучування) знань сприяє розвитку мислення. Окреслений діяльнісний підхід можна реалізувати шляхом застосування шкільного фізичного експерименту (далі - ШФЕ). Подальше вдосконалення управління процесом навчання засобами ШФЕ за умов сучасної школи $є$ однією 3 актуальних проблем дидактики фізики. ШФЕ перетворився 3 окремих дослідів у струнку систему навчального експерименту і $є$ одночасно джерелом знань, методом і засобом навчання ${ }^{\text {. }}$

Експериментальний метод дає можливість встановити причиннонаслідкові зв'язки між явищами, а також між величинами, які характеризують властивості тіл і явищ. Він $є$ як засобом пізнавальної інформації, так і засобом наочності.

Принцип системності з урахуванням діяльнісного підходу до аналізу навчального процесу дозволяє стверджувати, що ШФЕ пронизує діяльність учителя і учнів та інші основні компоненти, включаючи зміст курсу фізики, методи навчання, засоби навчання, форми навчальних занять. Оволодіння знаннями у процесі спостереження нерозривно пов'язане з розвитком мислення. ШФЕ посідає чільне місце у системі оволодіння навчальним матеріалом із фізики.

Управління навчальною діяльністю засобами ШФЕ ліквідовує певні суб'єктивні чинники, що впливають на цей процес. Важливим у ньому є: структура навчального матеріалу, місце ШФЕ у цій структурі. 3 погляду результатів освітнього процесу ШФЕ традиційно пов'язують із практичними уміннями учнів. У навчальному процесі 3 фізики експеримент $\epsilon^{2}$ :

${ }^{1}$ Бліндар В., Руденко М. Шкільний фізичний експеримент у сучасних умовах. Наукові записки. Серія Психолого-педагогічні науки. 2019. № 2. С. 51.

${ }^{2}$ Степанченко О.В., Чумак М.С., Сиротюк В.Д. Шкільний фізичний експеримент як засіб формування дослідницьких умінь учнів. Збірник наукових праць Кам'янецьПодільського начіонального університету імені Івана Огієнка. Серія педагогічна. Інновачійні технології управління якістю підготовки майбутніх вчителів фізикотехнологічного профілю. 2013. Вип. 19. С. 52. 
1. Методом дослідження фізичних процесів, забезпечує науковість і цілісність шкільного курсу.

2. Джерелом суб'єктивно нових для учнів емпіричних фактів, які виступають у ролі вихідних елементів в інтерпретації ї на основі концептуального змісту, що сприяє розвитку i становленню теоретичного знання.

3. Необхідним чинником у формуванні понятійного концептуального змісту та ідеалізованих об'єктів теоретичного знання, на основі якого з'являється і відтворюється суб'єктивно нове знання.

4. Засобом ілюстрації теоретичних побудов і висновків, забезпечуючи їм зв'язок з об'єктивною дійсністю та вихід теоретичних знань учнів у сферу практичної їх діяльності, тобто ілюструє використання теорії на практиці.

5. Основним засобом формування вмінь вести експериментальну роботу, що пробуджує інтерес до дослідження природи, розвиває мислення, активізує сприймання навчального матеріалу. Він формує в учнів специфічні для фізики вміння і навички, якщо вони самостійно «спілкуються» із приладами й установками.

6. Сприяє підвищенню наукового рівня шкільних курсів, формування наукового світогляду.

Перше, що слід відзначити, - це трактування ШФЕ як необхідного, але допоміжного дидактичного компонента навчання. Звідси логічно випливає висновок про необхідність визначення кількості дослідів у відношенні до досягнення цілей навчання. У системі ШФЕ цим практичним діям, які можна органічно поєднати з викладанням нового матеріалу, найкраще відповідає фронтальний дослід. Загальною і найбільш суттєвою ознакою всіх експериментальних робіт учнів $\epsilon$ фронтальний метод їх проведення. Важливо те, що роботи виконуються всіма учнями класу (групами або індивідуально) одночасно на одноманітному обладнанні під керівництвом учителя ${ }^{3}$.

Методично це поєднання зручно представити як суміщення часу, що витрачається на реалізацію двох основних компонент процесу навчання: викладання (викладу нового матеріалу вчителем - діяльності вчителя) й учіння (діяльності учнів). Суміщення двох діяльностей суб'єктів процесу навчання (учителя й учня), очевидно, може привести до інтенсифікації навчального процесу. Такий підхід до структури діяльності вчителя й учнів стимулював пошук і розробку нової моделі уроку, яка, по-перше, забезпечувала б увесь спектр умов для постійного розвитку пізнавальних можливостей учнів, їхнього мислення

3 Слюсаренко В. Фізичний експеримент у навчально-виховному процесі. Наукові записки Кіровоградського державного педагогічного університету імені Володимира Винниченка. Серія Педагогічні науки. 2013. Вип. 121 (1). C. 124. URL: http://nbuv.gov.ua/UJRN/Nz_p_2013_121(1)_31 
й активності, самостійності у навчальній роботі, по-друге, дала б можливість учителю гнучко управляти освітнім процесом для досягнення цілей навчання фізики.

На першому етапі моделювання процесу навчання фізики здійснювалося структурування навчального матеріалу. Для цього були виділені «узагальнені змістові одиниці» (далі - УЗО), кожну з яких складає елемент теоретичного змісту (поняття, явище, закон тощо), елемент експериментального змісту (предмети, з якими маніпулюють учні, у т. ч. обладнання та матеріали для виконання дослідів, повідомлення, настанови, запитання, вказівки вчителя щодо виконання дослідів) та елемент дидактичного змісту (посібники, зошити для учня, матеріали для контролю засвоєних знань тощо).

Враховувалися такі передумови:

1) необхідність засвоєння учнями великого обсягу навчального матеріалу за діючими навчальними програмами;

2) дефіцит часу на виклад навчального матеріалу;

3) наявність лабораторного обладнання;

4) необхідність строгого дотримання діючих програм із фізики;

5) вивчення можливостей інтенсифікації процесу навчання, зокрема за рахунок одночасного використання різних вербальних і невербальних дидактичних способів подачі матеріалу, що дозволяє повністю використовувати навчальний час.

Для відбору змісту ШФЕ нами з досвіду роботи вибрано такі критерії:

- найменші затрати часу, матеріалів, спеціального лабораторного обладнання;

- використання таких засобів навчання для проведення експерименту, які знайомі учням із повсякденного вжитку, власного попереднього досвіду, оскільки опора на життєвий досвід і знання учнів має велике значення;

- фронтальний експеримент має бути простий i доступний для виконання всіма учнями;

- зміст фронтальних дослідів має корелювати 3 теоретичним навчальним матеріалом із фізики;

- зміст фронтальних дослідів має повністю перекривати весь спектр теоретичних змістів діючих програм;

- змісти експериментів мають перекривати весь спектр демонстраційного експерименту, традиційно виконуваного вчителем, а також фронтальних дослідів і фронтальних лабораторних робіт, які повинні виконуватися згідно 3 діючими навчальними програмами з фізики;

- кількість пропонованих дослідів повинна бути надлишковою;

- експериментальні завдання повинні бути різної складності для забезпечення диференційованого підходу до учнів у процесі навчання згідно з вимогами програми; 
- експериментальні завдання мають забезпечити індивідуалізацію навчання;

- експериментальні завдання повинні сприяти як створенню (накопиченню) системи чуттєво-наочних образів, які $\epsilon$ матеріалом для подальшого засвоєння знань, так і створенню практичних проблемних ситуацій;

- інформація має надходити на різні сенсорні канали (зоровий, слуховий);

- діяльність учнів має переключатися з одного виду на інший;

- зміст експериментальних завдань детермінується реальними можливостями обладнання кабінетів фізики;

- експериментальні завдання повинні забезпечити вивчення основних (фундаментальних) теоретичних положень програмного матеріалу, тому здійснювалася селекція основного і другорядних змістів;

- зміст експериментальних завдань спрямований як на мимовільне, так і на довільне запам'ятовування;

- забезпечення вироблення в учнів інтелектуальних і практичних умінь і навичок;

- створення певних евристичних елементів у навчанні;

- підбір завдань повинен забезпечити зворотний зв'язок.

Уся сукупність відібраних експериментальних змістів повинна забезпечити реалізацію принципу систематичності та науковості знань.

Вибиралися такі теоретичні змістові одиниці (далі - ТЗО), що становлять основу базового курсу фізики, стосуються важливої інформації, без якої неможливий логічний виклад нового матеріалу. На їхній основі сформовано теоретичні та практичні завдання.

Для поєднання експериментального та теоретичного змістів потрібна ще одна ланка для управління процесом навчання. Потрібно відібрати такі змісти, які допоможуть вчителеві гнучко, лабільно управляти навчальною діяльністю учнів. Для цього відібрані певні настанови, запитання, підказки, вказівки щодо виконання дослідів. Завершену змістову структуру утворюють дидактичні матеріали: навчальні посібники, зошити для учня, матеріал для контролю засвоєння знань тощо ${ }^{4}$.

Експериментальні змістові одиниці (далі - ЕЗО) та ТЗО підбиралися 3 урахуванням особливостей перебігу психічних процесів в учнів

${ }^{4}$ Швай Р.І., Гірний О.І. Фізика 8. Робочий зошит. Львів : ВНТЛ, 2000. 116 с.

Швай P.І., Гірний О.І. Фізика. Навчальний комплекс «Три в одному». 7 клас: Робочий зошит. Харків : ВКФ “Гриф”, 2003. 88 с.

Швай Р.І., Гірний О.І. Фізика. Навчальний комплекс «Три в одному». 8 клас: Робочий зошит. Харків : ВКФ “Гриф”, 2003. 116 с.

Швай P.І., Гірний О.І. Фізика 7: Навчальний комплекс «Три в одному». Львів : Тріада плюс, 2005. 72 с. 
і психолого-фізіологічних їх особливостей. Як у ЕЗО, так і ТЗО представлена певна кількість інформації, невелика «порція», що сприяє кращому її запам'ятовуванню учнями. ТЗО подано у вербальній формі, ЕЗО - у невербальній (опора на зорові образи). Таке поєднання робить навчальний матеріал із фізики більш доступним і легшим для запам'ятовування. Запропоноване структурування інформації передбачає врахування та використання індивідуальних особливостей пам'яті учнів у плані існування двох іiі форм: чуттєво-образної та логіко-смислової.

Е3О впливають на першу іiі форму, причому у різних iï проявах: зоровій, слуховій, нюховій, моторній, тактильній. ТЗО - здебільшого на iii другу форму. Використаний теоретичний матеріал відіграє роль цементуючої логічної ланки у процесі подачі нового навчального матеріалу. Крім того, такий виклад матеріалу враховує індивідуальні особливості мислення учнів (словесно-логічне й образне). Для одних ЕЗО створюють наглядні опори, для інших ТЗО встановлюють змістові зв'язки у різноманітному конкретному матеріалі. Опора ЕЗО на попередній життєвий досвід учнів сприяє активнішому й успішному сприйняттю нового навчального матеріалу. Для кращого розуміння і запам'ятовування важливе врахування емоційного стану учнів, визначення ними значення запропонованого матеріалу. ЕЗО підбиралися так, щоб навчальний матеріал був різнорідним і цікавим для учнів, щоб він дивував, спонукав до дій, до здобування знань.

3 погляду часу урок - це послідовність навчальних дій вчителя й учнів. Якщо дії об'єднати у групи дій, що мають виразний праксеологічний початок і кінець (постановка завдання - результат виконання), то його можна зобразити у вигляді такої загальної схеми:

1) вчитель - 2) учні - 3) вчитель -4 ) учні ... - n) вчитель $-\mathrm{n}+1$ ) учні...

Наприклад: 1) вчитель - викладає новий матеріал, 2) учні слухають, 3) вчитель - дає завдання, 4) учні - виконують, n) вчитель дає завдання додому, $\mathrm{n}+1$ ) учні - слухають або записують.

Якщо замість 1), 2), 3), 4),.. n) поставити відповідні інтервали часу $\mathrm{t}_{1}, \ldots, \mathrm{t}_{\mathrm{n}}$, то урок можна виразити формулою:

$$
\mathrm{t}_{1}+\mathrm{t}_{2}+\mathrm{t}_{3}+\ldots+\mathrm{t}_{\mathrm{n}}=\mathrm{T}_{\text {уроку }}
$$

де $\mathrm{t}_{1}$ - пасивна пізнавальна діяльність (сприймання, учні слухають, дивляться); $\mathrm{t}_{2}-$ нейтральна діяльність (учні записують); $\mathrm{t}_{3}-$ активна пізнавальна діяльність (учні розв'язують задачі, виконують дослід, читають підручник, дають відповідь на запитання вчителя тощо); $\mathrm{t}_{\mathrm{n}}$ - нейтральна діяльність (записування завдання).

Різні інтервали часу позначають пізнавальну діяльність трьох видів, яку можна умовно назвати пасивною, нейтральною, активною. 3 усього 
часу уроку пізнавально використовується: $\mathrm{t}_{1}+\mathrm{t}_{3}=\mathrm{T}_{\text {уроку }}-\mathrm{t}_{2}-\ldots-\mathrm{t}_{\mathrm{n}}$, тобто не весь час уроку.

Якщо здійснити суміщення часу активної (дослідної) пізнавальної діяльності учнів із викладом нового матеріалу вчителем, то це досягається за допомогою іншої часової схеми уроку, котру умовно можна назвати паралельною або паралельно-послідовною. За цією схемою відбувається суміщення в часі різних видів діяльності. Цим можна добитися того, що сумарний навчальний час уроку стає навіть більший, ніж його фізичний час. ШФЕ у такій схемі стає не просто одним із головних, а деколи й головним дидактичним компонентом уроку, на фоні якого реалізовуються всі інші.

Відповідно до запропонованих двох схем уроку вивчення теоретичного матеріалу (понять, законів тощо) характеризується двома групами ознак.

У послідовній схемі вивчення відбувається:

а) пасивно: вчитель викладає - учні слухають;

б) умоглядно: вчитель запитує - учні відповідають.

У паралельній схемі вивчення відбувається:

а) активно: учні запитують - учитель відповідає або учні самостійно здійснюють пошук і знаходять відповіді;

б) практично-дієво: учні виконують якесь завдання i засвоюють теоретичний матеріал у ході виконання завдання.

Як наслідок, теоретичний матеріал краще засвоюється, хоча спеціально на цьому не акцентувалося.

Таким чином, психологічне (чи когнітивне) підгрунтя цих схем $\epsilon$ різним. У послідовній схемі:

a) увага сконцентрована на теоретичному матеріалі так, що основна діяльність має лише (переважно) умоглядний характер;

б) практика використовується як допоміжний дидактичний засіб для закріплення теорії;

в) вивчення теоретичного матеріалу 3 необхідністю передбачає окремий час на пасивне його сприйняття (інтенсивність навчання менша).

У паралельній схемі:

a) увага розподілена (строго й акуратно вчителем) так, що основна спрямована на практичну діяльність (виконання завдання);

б) практика використовується як основний дидактичний засіб навчання;

в) вивчення теоретичного матеріалу не обов'язково передбачає окремий час на його пасивне сприйняття (інтенсивність навчання більша).

Таким чином, у викладанні базового курсу фізики основними дидактичними компонентами процесу навчання $\epsilon$ компоненти практичні, що майже повністю (за винятком демонстрацій) підпадають 
під класичне визначення системи шкільного фізичного експерименту. Вчитель забезпечує стійкість уваги - довготривале утримування уваги учнів на навчальній діяльності. Це забезпечується активною і різноманітною практичною діяльністю учнів, їхньою активною розумовою діяльністю. Крім того, вчитель привчає до розподілу уваги учня, ставлячи його у відповідні умови. Тому з часом, 3 набуттям певних практичних умінь учень може розподіляти увагу між двома або декількома об'єктами за одночасного виконання дій із ними. Розподіл уваги не викликає особливих труднощів, оскільки хоча б одна дія 3 кількох уже є звичною і не потребує зосередженої уваги. Крім того, учитель засобами ШФЕ здійснює переключення однієї діяльності на іншу, що запобігає втомі та відволіканню уваги. Правильний відбір дослідів робить працю учнів на уроці цікавою, емоційно захоплюючою, що сприяє запам'ятовуванню, концентрації уваги на безпосередній роботі, активізації розумової діяльності. За такої організації навчального процесу учні не можуть бездумно слухати вчителя. Учень включений у безпосередню практичну (активну) діяльність. Вдало відібраний експеримент підвищує інтерес учнів до вивчення навчального предмету. 3 одного боку, це не потребує певного вольового зусилля учня для засвоєння матеріалу, з іншого - матеріал засвоюється (запам'ятовується) ніби на другому плані. Запам’ятовуваний матеріал є об'єктом діяльності учнів. Питання, підказки, окремі усні інструкції вчитель спрямовує на довільну увагу учнів. Звертаємо увагу на те, що експериментальні та теоретичні змістові одиниці згруповано так, щоб об'єм інформації відповідав наявному об'єму пам'яті учня.

Кількість змістових одиниць (i теоретичних, і практичних) може бути різною залежно від їхнього змістового наповнення. Важливо, щоб вона була «надлишковою» стосовно всієї групи учнів, а зміст - жорстко пов'язаний із програмою. Така модель навчання дає можливість реалізувати дитиноцентрований індивідуальний підхід та особистісно орієнтоване навчання. Можна повною мірою враховувати особливості психічних процесів кожного учня, особливості його мислення, пам'яті. Це досягається створенням учням умов для роботи у відповідному їм індивідуальному темпі сприймання й обробки інформації. Здійснюється це регулюванням швидкості введення нових завдань (змістових одиниць). Так реалізовується індивідуалізація навчання. Використовуючи розроблену модель, можна фактично навчати усіх учнів за єдиною програмою (за обсягом і змістом) та одночасно здійснювати індивідуальний підхід. Учень засвоює навчальний матеріал із фізики у темпі, який відповідає його індивідуальним особливостям. У зв'язку з цим розглянемо проблему диференціації навчання. Пропонуємо розрізнити поточну та загальну диференціацію. Поточна диференціація полягає у: 
- множинності підбору ЕЗО для ТЗО. Так звані «швидкі» учні можуть виконувати надлишкову кількість ЕЗО, тоді як «помірні» чи «повільні» - якусь їх частину, однак теоретичний матеріал будуть засвоювати усі категорії учнів в однаковому об'ємі незалежно від темпу роботи;

- маючи повне дидактичне забезпечення (посібник для вчителя, робочий зошит для учня, навчальні підручники, набір обладнання), «швидкі» учні можуть працювати самостійно. Учитель здійснює контроль за роботою через, наприклад, опитування. Свою основну увагу він спрямовує на учнів із низьким рівнем виконавської діяльності («повільних»), із труднощами у сприйманні та засвоєнні матеріалу.

Таким чином, за умов масової школи розроблена модель навчання створює сприятливі умови для здійснення індивідуалізації й особистісно орієнтованого навчання.

Управління навчальною діяльністю учнів у цій моделі здійснюється через загальну диференціацію. Під цим розуміємо підпорядковане певним критеріям структурування навчального матеріалу. Зроблена модифікація змісту забезпечує структурування навчального матеріалу через узагальнені змістові одиниці, кожну з яких складають елементи теоретичного й експериментального змісту. Загальна диференціація зроблена зі збереженням логічного викладу навчального матеріалу 3 фізики й урахуванням особливостей пам'яті та мислення учнів.

Роль ШФЕ у нашій моделі детермінується:

- важливістю емпіричних знань для вивчення фізики на початкових етапах у базовій школі;

- необхідністю набування певних практичних умінь і навичок у процесі виконання експерименту;

- значенням ШФЕ для оволодіння навчальним матеріалом із фізики;

- вищим рівнем взаємозумовленості та взаємозв'язку логікомислительних і практичних дій учнів.

ШФЕ, який є посередині інформаційних потоків «учитель - учень», спонукає учня спрямувати свою навчальну діяльність на здобування знань, набуття пізнавальних умінь, навичок, на розвиток логікомислительних процесів, інтеріоризацію змісту. Діяльність учителя здебільшого управлінська, але має менший об'єм, ніж у традиційному навчанні. Частину своїх управлінських функцій він передає учневі. У паралельній схемі навчання учень - це співкерівник навчальної діяльності. У цій моделі навчання безпосередня взаємодія «учень учитель» відсутня. Вона опосередкована ШФЕ. Множинність ЕЗО, виконання їх учнями, відповіді учнів на запитання у процесі виконання дослідів, висновки, які вони роблять, набування певних практичних умінь і навичок дає вчителеві інформацію про сприймання, розуміння 
учнями програмного матеріалу. Такий безперервний зворотний зв'язок дає вчителеві можливість вносити корективи в інформаційні потоки. Інформація, що надходить до учня у процесі виконання ним практичних дій, не може бути фактом простої іiі механічної передачі. Самостійне виконання учнями завдань системи ШФЕ створює найкращі можливості для такого зворотного зв'язку. Діяльність учнів у процесі виконання завдання дає змогу учителю робити висновок про рівень засвоєння та закріплення матеріалу. Зовнішній зворотний зв'язок можна здійснюватися не лише безпосередньо, але з інтервалом у часі (письмове опитування у вигляді короткочасних самостійних робіт та інших видів поточного, тематичного, атестаційного контролю).

ШФЕ у цій моделі навчання має ще й іншу площину у здійсненні зворотного зв'язку. Підбір ЕЗО забезпечує багатосторонні зв'язки нового навчального матеріалу і системою попередньо засвоєних знань і вмінь. Правильність наступних дій дає вчителеві можливість визначити рівень засвоєння попередніх. Система ЕЗО та ТЗО сприяє не лише формуванню практичних умінь i навичок, але й логіко-мислительних операцій у свідомості учнів, інтелектуальних умінь і навичок. Взаємозв'язок практики та розумових, психічних процесів реалізує дидактичні цілі у процесі навчання фізики. Новий матеріал засвоюється у процесі розв'язування нових завдань. Така подача матеріалу формує певні навички сприймання, що може допомогти у подальшій (творчій) діяльності.

Зворотний зв'язок у змодельованій схемі дає можливість учням самим здійснювати поточну диференціацію. У цьому разі учень бере на себе частину управлінських функцій. Учень сам дозує подачу навчального матеріалу у найбільш сприятливому для себе режимі. Загальна диференціація полегшує здійснення поточної диференціації, оскільки таке структурування матеріалу дає можливість збільшувати чи зменшувати швидкість введення узагальнених змістових одиниць. Управляє учень своєю навчальною діяльністю через ШФЕ, оскільки отримання інформації відбувається за описаною схемою, тобто через подачу ЕЗО. Схема інформаційних потоків не змінюється. Учень лише змінює швидкість їх введення.

Різна швидкість введення нових УЗО дає вищу інтенсивність навчання та розширює можливості індивідуального підходу, зокрема у вигляді поточної диференціації, побудованої на різній швидкості засвоєння ТЗО й ЕЗО. Учні з більшою швидкістю засвоєння можуть виконати більшу кількість ЕЗО, працюючи майже самостійно, тому вчитель основну увагу спрямовує на учнів із низьким темпом навчання (пізнавальні можливості (здібності) учнів різні, але вони змінюються у процесі навчання). Виконання завдань системи ШФЕ дозволяє учням самим диференціювати процес навчання, дозуючи подачу ЕЗО у найсприятливішому для себе режимі, управляючи своєю діяльністю (учінням). Така диференціація також допомагає учням зі слабким 
абстрактно-логічним мисленням базувати його на наочних опорах, а учням зі слабким наочно-образним - розширювати арсенал чуттєвих образів. Обидва компоненти мислення потрібні для розв'язування завдань на творчому (найвищому) рівні.

\section{ВИСНОВКИ}

Зі зміною педагогічного розуміння предмета управління в освітньому процесі пов'язана зміна у постановці відповідного завдання управління: від передавання заданої наперед кількості та якості інформації 3 найменшими затратами часу, матеріалів, енергії тощо до завдання за наперед заданих затрат часу, матеріалів тощо передати якнайбільшу кількість якісної інформації.

Для розв'язання цього завдання запропонована модель управління процесом навчання, побудована на основі діяльнісного підходу. Сфера застосування діяльнісного підходу до навчання фізики об'єднується дидактами у поняття системи ШФЕ. У теорії навчання його місце визначене під час вивчення фізичних законів, явищ і властивостей, що неявно вказує на поєднання в часі теоретичного i практичного навчального матеріалу. Це поєднання зручно представити як суміщення часу, який затрачається на викладання (діяльність вчителя) й учіння (діяльність учнів). Розроблена модель інтенсивного навчання фізики, в основу якої покладаються три ідеї: суміщення в часі діяльності вчителя й учня; конструювання змісту діяльності учня на основі системи ШФЕ; використання ШФЕ як основного засобу управління процесом навчання фізики. Управління процесом навчання у розробленій моделі запропоновано здійснювати 3 допомогою УЗО, що складаються з теоретичних i експериментальних змістових одиниць, поєднаних у завершену структуру навчальних посібників, укладених для експериментальної перевірки створеної моделі. Виконання завдань системи ШФЕ дозволяє учням самим диференціювати процес навчання, дозуючи подачу ЕЗО у найсприятливішому для себе режимі, управляючи своєю діяльністю (учінням).

\section{АНОТАЦІЯ}

Освітній процес розглянуто 3 погляду теорії управління. Сформульовано нове завдання управління процесом навчання: від передачі заданої наперед кількості та якості інформації з найменшими затратами часу, матеріалів, енергії тощо до передачі якнайбільшої кількості та якості інформації за наперед заданих затрат часу, матеріалів тощо. Розроблено модель процесу навчання фізики, побудовану на суміщенні в часі діяльності учителя й учня та конструюванні змісту діяльності учня із застосуванням ШФЕ як провідного засобу управління процесом навчання. ШФЕ дозволяє повністю реалізувати діяльнісний та індивідуальний підхід у навчанні. 
В основу моделі покладено дидактичну формулу та відповідну схему уроку, побудовані на діяльнісній інтерпретації параметра навчального часу. Модель навчання дозволяє залучати всіх учнів до безперевної активної пізнавальної діяльності. Вивчення теоретичного матеріалу не обов'язково передбачає окремий час на його пасивне сприйняття (інтенсивність навчання більша).

\section{ЛITЕРАТУРА}

1. Бліндар В., Руденко М. Шкільний фізичний експеримент у сучасних умовах. Наукові записки. Серія Психолого-педагогічні науки. 2019. № 2. C. 8-13. DOI: https://doi.org/10.31654/2663-4902-2019-PP-2-8-14.

2. Степанченко О.В., Чумак М.Є., Сиротюк В.Д. Шкільний фізичний експеримент як засіб формування дослідницьких умінь учнів. Збірник наукових праць Кам'янець-Подільського національного університету імені Івана Огієнка. Серія педагогічна. Інноваиійні технології управління якістю підготовки майбутніх вчителів фізикотехнологічного профілю. 2013. Вип. 19. С. 51-55.

3. Слюсаренко В. Фізичний експеримент у навчально-виховному процесі. Наукові записки Кіровоградського державного педагогічного університету імені Володимира Винниченка. Серія Педагогічні науки. 2013. Вип. 121 (1). С. 122-126. URL: http://nbuv.gov.ua/UJRN/Nz_p_2013_121(1)_31.

4. Швай P.І., Гірний О.І. Фізика 8: Робочий зошит. Львів : ВНТЛ, 2000. $116 \mathrm{c}$.

5. Швай P.I., Гірний О.I. Фізика: Навчальний комплекс «Три в одному». 7 клас: Робочий зошит. Харків : ВКФ «Гриф», 2003. 88 с.

6. Швай P.I., Гірний О.I. Фізика: Навчальний комплекс «Три в одному». 8 клас: Робочий зошит. Харків : ВКФ «Гриф», 2003. 116 с.

7. Швай P.I., Гірний О.І. Фізика 7: Навчальний комплекс «Три в одному». Львів : Тріада плюс, 2005. 72 с.

\section{Information about the author:} Shvay R. I.,

Doctor of Pedagogical Sciences, Full Professor, Professor at the Department of Pedagogy and Innovative Education Institute of Law, Psychology and Innovative Education of the Lviv Polytechnic National University 12, Stepana Bandery str., Lviv, 79000, Ukraine 